\title{
Characterization of Biodiesel from Alkaline Refinement of Waste Cooking Oil
}

\author{
Aliru Olajide Mustapha*, Amina Abiola Adebisi, Bukola Opeyemi Olanipekun \\ Department of Chemical, Geological \& Physical Sciences, Kwara State University Malete, PMB 1530, \\ Ilorin, Kwara State, Nigeria \\ * Corresponding author email: aliru.mustapha@kwasu.edu.ng
}

Received: 28 May 2020 / Revised: 03 August 2020 / Accepted: 20 August 2020 / Published: 04 September 2020

\begin{abstract}
The waste cooking oil (WCO) is a low cost and prospective feedstock with no competitive food uses for biodiesel production, but the yield and quality have been greatly affected by impurities. This study examined the chemical and fuel quality of biodiesel of both WCO and alkaline treated WCO. The transesterification process using the alkaline treated cooking oil (ACO) methanol and sodium hydroxide as catalyst followed the Association of Officials of Analytical Chemists (AOAC) techniques. The $\mathrm{pH}$ values between 7.27 and 8.65 were found for alkaline treated cooking methyl ester (ACME), alkaline treated cooking oil (ACO) and WCO. Density of ACME, ACO and WCO varied between 0.89 and $0.93\left(\mathrm{~g} / \mathrm{cm}^{3}\right)$. The fatty acids found were benzoic acid $(3.77 \%)$, octanoic acid $(8.35 \%)$, and palmitic acid $(75.02 \%)$ - most abundant. Comparison of results with the American Standard for Testing Materials (ASTM) values showed quality enhancements of ACO in physicochemical and fuel properties over WCO. The biodiesels from ACO have enhanced emulsification, fuel and free fatty acids qualities over the WCO, showing the refinement methodology of WCO has overall improvement in the biodiesel purity and quality against the previous conflicting reports.
\end{abstract}

Keywords: biodiesel, waste cooking oil, alkaline treatment, fatty acid, physicochemical.

\section{Introduction}

The non-utilization of waste cooking oil in the further production food has made it important feedstock for biodiesel in recent times. In most developing countries, biodiesel appears to supply a bigger probability for an honest complement to fossil fuels. Most of economies today are for the most part agricultural, therefore the crops needed for biodiesel production are cultivated in lots of abundance. The biodiesel technology and procedures are straightforward that may be practiced, even by rural dwellers [1, 2]. Additionally, the resultant fuel is environmentally friendly, sustainable and doesn't need petroleumdiesel engine modification. Biodiesel production additionally guarantees to deal with the problems of poor electricity generation in rural areas, perennial fuel inadequacy and environmental pollution through use of generated materials [3, 4]. Many alternative sources of waste cooking oil (WCO) include business, domestic, and industrial sectors. WCO has to be properly managed as it might be a likely problematic waste stream once disposed incorrectly, and the oil solidifies down the sinks. The WCO is sometimes problematic as its disposal quickly causes blockages of sewer pipes $[5,6]$. Several previous reports have calculated the worth of biodiesel production with assumptions regarding its production volume, feedstock and chemical technology developed, with a moderately-sized industrial biodiesel production facility model to estimate the capital and operational cost [7-10]. About $88 \%$ of total costs of biodiesel production were reported by authors to be from the vegetable oils [11, 12]. Both Kulkarni and Dalai [13, 14] used various 
Characterization of Biodiesel from Alkaline Refinement of Waste Cooking Oil

designs and production plants with a technoeconomic analysis to match other alternatives.

The used vegetable oil once degraded gets into sewage works where their properties causes corrosion of metal and additionally affects installations in waste water treatment plants. Waste treatment of effluent due to WCO disposals is another environmental concern. Therefore, the use of refined waste cooking edible vegetable oils and animal fats as non-food materials for biodiesel production may be a good alternative in our search for cheaper fuel sources in the future and therefore require investigation. The issues of biodiesel feedstock contending with the food offer in the long-run is being eliminated as WCO for biodiesel is non-food sensitive. This work hopes to evaluate the fuel properties and free fatty acids composition of alkaline treated cooking oil (ACO) and demonstrate that new refinement methodology of WCO in the biodiesel purity has overall improvement against the previous conflicting reports [15-18]

\section{Research Methodology}

Chemicals and equipment were obtained from Cerrilliant (Round Rock, TX, USA LGC (Teddington Middlesex, UK), Aldrich Sigma (Gillingham Dorset, UK). Biodiesel analyzed using reflux set, micro-pipette, separating funnel, digital hot plate/magnetic stirrer, regulated waterbath, pycnometer (ASTM D941), pH scale meter (Hanna HI 4212 model), calorimeter (Parr-1351 from Parr Instrument Company, Moline, IL, USA), Cannon-Fenske viscometer ostwald (Cannon Instrument Co., State College, PA, USA) Waste oil (WCO) of sunflower (helianthus) was obtained from a food building in $\mathrm{Oja} \mathrm{Oba}$, Ilorin, Kwara State, Nigeria at Degree Minutes Seconds (DMS) coordinates (Latitude: 8० 29' 47.90" N Longitude: 4o 32'31.70” E). It was made from deep frying of foods and was used as feed stock for biodiesel production. Waste vegetable oil (WCO) purification was subjected to alkaline treatment process that concerned with removing impurities before economical transesterification to supply ACO. The alkaline treated oil (ACO) was measured, heated to 100 OC and activated charcoal added to the mixture for 45 minutes with constant stirring. The acid esterification required the free acid (FFA) value to be brought below 0.5, for the transesterification to proceed $[19,20]$. Transesterification technique of ACO to alkaline treated cooking methyl ester (ACME) was the mixture of ACO and methyl alcohol, heated and stirred for 1 hour at $65^{\circ} \mathrm{C}$, at oil to methyl alcohol molar relation of 1:6 in the presence of $\mathrm{NaOH}$ as catalyst $[21,22]$. The WCO, ACO, and ACME properties were evaluated by the Association of officials of Analytical Chemists [23, 24], and American Society for Test and Material (ASTM) for quality evaluations [25]. Specifically, chemical properties like acid value $(\mathrm{mgKOH} / \mathrm{g})$ by American Oil Chemists' Society (AOCS) Official technique [26], iodine value $\left(\mathrm{mgI}_{2} / 100 \mathrm{~g}\right)$, peroxide value $\left(\mathrm{MeqO}_{2} / \mathrm{Kg}\right)$ by AOCS Official technique [27], saponification $(\mathrm{mgKOH} / \mathrm{g})$ [23], and free fatty acids by AOCS Official technique [28]. The pour, flash, cloud, smoke points, specific density, higher heating value, kinematic viscosity, and cetane number (ASTM D6751-09) [29]. Determination of free fatty acids profile of ACME: Gas Chromatography Mass Spectrometry (GC-MS) analysis was conducted with Varian 3800 gas -chromatography together with Agilent MS capillary column (30 m x zero. 25 $\mathrm{mm}$ i.d) [23]. FTIR analysis done with Shimadzu instrument. $\mathrm{KBr}$ (Potassium bromide) was grounded into (powdery form) pelletized (with hydraulic press) and scanned at a frequency vary of $4000-400 \mathrm{~cm}^{-1}$.

\section{Results and Discussion}

\subsection{Chemical properties of WCO, ACO, and ACME}

The Table 1 presents the chemical properties obtained for WCO, ACO, and ACME. The level of acid value was drastically reduced after alkaline treatment of WCO to ACO $(2.42 \mathrm{mgNaOH} / \mathrm{g})$. The acid values of $5.89 \mathrm{mg} / \mathrm{g}$ found in WCO before refinement was very high, which may result to larger form of free fatty acids out there among the oil but due to continuous hydrolytic cleavage of bonds.

Throughout preparation processes, the massive reduction of $61.5 \%$ FFA observed in the ACO was a prospect of the used oils, and it's gained 
Aliru Olajide Mustapha et al., Int. Ann. Sci.; Vol. 10, Issue 1, pp: 16-24, 2021

higher domestic and industrial use with improved resistance to oxidative damage. The acid values were: WCO (5.89 $\mathrm{mg} / \mathrm{KOH})$, ACO (2.42 $\mathrm{mg} / \mathrm{KOH})$ and ACME (0.04 $\mathrm{mg} / \mathrm{KOH})$, respectively. However, the amount obtained throughout this work was considerably not up to the $6.1721 \mathrm{mg} / \mathrm{KOH}$ from the biodiesel made of waste oil claimed by [19-21]. The acid values ranges of $1.32-3.6 \mathrm{mg} / \mathrm{KOH}$ have in addition had been reported for waste cooking oil in the literature by Muhammad and Bhargavi [30].
Omojola, et al., [31] gave the acid values of some waste cooking oils like sunflower, margarine, sunf oil and palmoil as 2.29, 2.87, 0.72 and 0.66 $(\mathrm{mg} / \mathrm{KOH})$ against the value of $5.89 \pm 0.14$ $(\mathrm{mg} / \mathrm{KOH})$ discovered throughout this work. However, value of $0.04 \mathrm{mg} / \mathrm{KOH}$ given for RCME here falls at intervals of the ASTM D6751-09 Standards $(<0.8 \mathrm{mg} / \mathrm{KOH})[5,6]$. The peroxide value of $\mathrm{WCO}$ when alkaline treated ranged from 2.60 to $1.88 \mathrm{MeO}_{2} / \mathrm{kg}$, representing $26.9 \%$ reductions.

Table 1: Chemical and fuel properties of waste, treated cooking oil and biodiesel

\begin{tabular}{|c|c|c|c|c|c|}
\hline Properties & $\begin{array}{l}\text { Waste cooking } \\
\text { oil (WCO) }\end{array}$ & $\begin{array}{l}\text { Alkaline-treated } \\
\text { cooking oil } \\
(\mathrm{ACO})\end{array}$ & $\begin{array}{l}\text { Comparable } \\
\text { differences } \\
(\%)\end{array}$ & $\begin{array}{l}\text { Alkaline- } \\
\text { cooking methyl } \\
\text { ester } \\
(\mathrm{ACME})\end{array}$ & $\begin{array}{l}\text { ASTM } \\
\text { D6751-09 } \\
\text { \&EN14214 }\end{array}$ \\
\hline \multicolumn{6}{|c|}{ Chemical properties } \\
\hline $\begin{array}{l}\text { Acid value, } \\
(\mathrm{mg} / \mathrm{KOH})\end{array}$ & $5.89 \pm 0.14$ & $2.42 \pm 0.02$ & 61.5 & $0.04 \pm 0.01$ & $<0.8$ \\
\hline $\begin{array}{l}\text { Saponification, } \\
(\mathrm{mg} / \mathrm{KOH})\end{array}$ & $197.50 \pm 2.12$ & $181.14 \pm 0.01$ & 10.8 & $222.45 \pm 0.01$ & $<312$ \\
\hline $\begin{array}{l}\text { Iodine Value, } \\
\left(\mathrm{I}_{2} / 100 \mathrm{~g}\right)\end{array}$ & $146.64 \pm 0.23$ & $142.03 \pm 0.2$ & 4.9 & $132.01 \pm 0.02$ & $<120$ \\
\hline $\begin{array}{l}\text { Peroxide Value, } \\
\left(\mathrm{Meq} \mathrm{O}_{2} / \mathrm{kg}\right)\end{array}$ & $2.60 \pm 0.00$ & $1.98 \pm 0.01$ & 26.9 & $2.94 \pm 0.01$ & 10 \\
\hline $\begin{array}{l}\text { Ester value, } \\
(\mathrm{mg} / \mathrm{KOH})\end{array}$ & $191.61 \pm 2.0$ & $173.72 \pm 0.01$ & 7.0 & $222.41 \pm 0.01$ & - \\
\hline $\begin{array}{l}\text { Calorific value } \\
(\mathrm{J} / \mathrm{Kg})\end{array}$ & -8180.57 & -7485.26 & 8.5 & -9027.1 & - \\
\hline Glycerine (\%) & 10.47 & 9.77 & 7.1 & 12.16 & \\
\hline FFA $(\%)$ & 2.96 & 1.21 & 59.2 & 0.02 & 0.5 \\
\hline \multicolumn{6}{|l|}{ Fuel properties } \\
\hline Yield (\%) & 100 & 93.1 & 8.5 & 94.5 & - \\
\hline $\mathrm{pH}$ & 8.65 & 7.27 & 8.0 & 5.57 & - \\
\hline Specific gravity & 0.95 & 0.91 & 6.3 & 0.89 & $0.86-0.92$ \\
\hline $\begin{array}{l}\text { Density at } 40^{\circ} \mathrm{C} \\
\left(\mathrm{g} / \mathrm{cm}^{3}\right)\end{array}$ & 0.93 & 0.91 & 2.2 & 0.88 & 0.88 \\
\hline $\begin{array}{l}\text { Kinematic } \\
\text { viscosity } \\
\text { at } 40^{\circ} \mathrm{C}\left(\mathrm{mm}^{2} / \mathrm{s}\right)\end{array}$ & 38.40 & 17.6 & 54.2 & 2.70 & $1.90-6.0$ \\
\hline $\begin{array}{l}\text { Cetane number } \\
(\min )\end{array}$ & 35.5 & 44.48 & 25.2 & 41.14 & $\geq 47$ \\
\hline Smoke point, $\left({ }^{\circ} \mathrm{C}\right)$ & 194 & 139 & 30.9 & 131 & 130 \\
\hline Flash point, $\left({ }^{\circ} \mathrm{C}\right)$ & 149 & 140 & 12.1 & 146 & 150 \\
\hline Fire point, $\left({ }^{\circ} \mathrm{C}\right)$ & 185 & 175 & 10.8 & 169 & 170 \\
\hline Pour point, $\left({ }^{\circ} \mathrm{C}\right)$ & -3 & -4 & 2.3 & -17 & -20 \\
\hline $\begin{array}{l}\text { Higher heating } \\
\text { value }(\mathrm{MJ} / \mathrm{kg})\end{array}$ & 44.50 & 43.70 & 0.7 & 42.01 & $\begin{array}{l}\mathrm{EN} 14214 \\
35 \mathrm{MJ} / \mathrm{kg}\end{array}$ \\
\hline
\end{tabular}


Characterization of Biodiesel from Alkaline Refinement of Waste Cooking Oil

The variations in peroxide values of 65.76 and $59.64 \mathrm{MeO}_{2} / \mathrm{kg}$ were discovered from refinement of pongamia pinnata and citrullus. colocynthis oils were earlier reported [20]. However, this peroxide values falls at intervals of the required value for peroxide recommended by Codex $\left(10 \mathrm{meq} \mathrm{O}_{2} / \mathrm{kg}\right)$ for oil/fat deterioration [36]. Also, $2.84 \pm 0.02$ (Meq O2/kg) reported for RCME falls at intervals of the ASTM D6751-09 standards of 10 $\mathrm{MeO}_{2} / \mathrm{kg}[17,20]$. The iodine values obtained for WCO (146.64 I2/100g), ACO (142.03 I $/ 100 \mathrm{~g})$ and ACME (132.01 $\left.\mathrm{I}_{2} / 100 \mathrm{~g}\right)$ shows outstanding improvements. The slight reduction of $4.9 \%$ in iodine value of WCO was discovered after alkaline treatment. This result shows the alkaline treated WCO possessed higher oxidative stability which can be used for industrial applications. Duhan, et al., [38] reported a reduction rate of $25.59 \%$ and $27.37 \%$ of iodine values of two samples of WCO after treatment. Omojola et al., [31] reported the iodine values of some WCO like sunflower, margarine, sunf oil and palm oil as $111.1,54.9,116.7$ and $81.7(\mathrm{mg} / \mathrm{KOH})$ against the iodine value of $5 . .89 \pm 0.14(\mathrm{mg} / \mathrm{KOH})$ discovered in this work. The iodine value of $117.99 \pm 0.67 \mathrm{I} 2 / 100 \mathrm{~g}$ discovered in this work were equivalent to the iodine values determined elsewhere and in addition falls at intervals of the ASTM D6751-09 standards [25].

The results for saponification value show that every WCO and ACO includes fatty acids of moderate long chain lengths (C16-C20) due to their relatively low saponification values, i.e. each of WCO (197.50 mg/KOH) and ACO (181.11 $\mathrm{mg} / \mathrm{KOH})$ have saponification value below ASTM recommended value ( $\geq 312 \mathrm{mg} / \mathrm{KOH})$. Duhan, et al., [38] similarly reported increase in the saponification value of 13.43 and 13.46 $\mathrm{mg} / \mathrm{KOH}$ for citrullus. colocynthis and pongamia pinnata oils after refinement/treatment. The saponification value ranges of 188.2 - 207 $\mathrm{mg} / \mathrm{KOH}$ were reported by Muhammad and Bhargavi [30] indicating the suitability of oil capable of extra applications.

\subsection{Fuel properties of WCO, ACO, and ACME}

\subsubsection{The recovery percentage}

The yield of ACO from WCO was 93.1\%, whereas the yield of DCME was 94.5\%. Biodiesel yields from waste vegetable oil by two ways of microwave heating and convectional heating in the literature had created $92 \%$ yield with no refinement. Alkaline treatment of the WCO to ACO thus exaggerated the yield of oil

\subsubsection{Specific gravity}

In Table 1, the specific gravity values for $\mathrm{WCO}$ and ACO were between $0.95-0.89$ and biodiesel was 0.89 was found. Specific gravity are very important factors within the international edible oil trade market with an applicable limit of 0.86 - 0.92 (ASTM D6751-09). Decrease in the specific density of 0.89 was as results of the removal of unwanted substances like free fatty acids, and completely different chemical product in the oil. Similar reduction in specific density (0.87) was obtained for the refinement of waste cookery oils of Baphia nitida and Gliricidia sepium [32].

\subsubsection{Density and kinematic viscosity}

Fuel density affects fuel performance. Alternative fuel properties, like heating value and viscosity are powerfully connected to density. Fuel density is one altogether the factors that have a sway on the atomization and combustion. The densities for WCO, ACO and ACME obtained were 0.93, 0.91, and 0.88 ( $\mathrm{g} / \mathrm{cm} 3)$, respectfully. Muhammed and Bhargavi [30] earlier reported the density ranges of $0.91-0.92(\mathrm{~g} / \mathrm{cm} 3)$ and Rahadanti et al., [19] equally gave $0.91(\mathrm{~g} / \mathrm{cm} 3)$ for WCO. Omojola, e al., [31] reported the densities of some WCOs like flower, oleomargarine, sunfoil and palmoil as $0.920,0.917,0.920$ and $0.904(\mathrm{~g} / \mathrm{cm} 3)$ against the discovered density of $0.93 \mathrm{~g} / \mathrm{cm} 3$ found for WCO during this study. This recommends that biodiesel from treated WCO with the alkali $(\mathrm{NaOH})$ as catalyst would have higher fuel performance because of its lower density of 0.88 [25]. The oil viscosity once treated with the alkaline (ACO) is in Table 1. Viscosity is usually perceived as thickness, or resistance to running. Ryan, et al., [33] reported the viscosity of vegetable oils is influenced in the main by fatty acid composition and quantity of contaminants. Kinematic viscosities of WCO, ACO and ACME were found to be $38.40,17.60$, and $2.70 \mathrm{~mm}^{2}$ at 
Aliru Olajide Mustapha et al., Int. Ann. Sci.; Vol. 10, Issue 1, pp: 16-24, 2021

$40^{\circ} \mathrm{C}$. Prafulla, et al., [34] reported viscosity of $28.8 \mathrm{~mm}^{2}$ at $40{ }^{\circ} \mathrm{C}$ for $\mathrm{WCO}$ and $6.25-3.10 \mathrm{~mm}^{2}$ at $40^{\circ} \mathrm{C}$ for biodiesel. The value of $88.88 \mathrm{~mm}^{2}$ at $40^{\circ} \mathrm{C}$ was given by Rahadanti, et al., [19] for viscosity characteristic determination. Kinematic viscosity had been reported by Maurizio, et al., [35] in the ranges of $36.4-42 \mathrm{~mm}^{2}$ at $40^{\circ} \mathrm{C}$ in line with ASTM (2003) specifications for biodiesel. Kinematic viscosity property ought to be between the 1.9-6.0 $\mathrm{mm}^{2} / \mathrm{s}$. The kinematic viscosity value of $2.70 \mathrm{~mm}^{2}$ at $40^{\circ} \mathrm{C}$ was higher to international standards for biodiesel. Also, Omojola, et al., [31] reported the viscosities at $40^{\circ} \mathrm{C}$ of WCOs like sunflower, margarine, sunfoil and palmoil as 31.38, 40.93, 43.52 and 44.25 $\left(\mathrm{mm}^{2} / \mathrm{s}\right)$ against the determined kinematic viscosity of $38.40 \mathrm{~mm}^{2} / \mathrm{s}$ reported in this work.

\subsubsection{Cetane number}

Cetane number of fuels indicates the degree of its ignition feature for compression ignition engines. The high cetane range of every $\mathrm{ACO}$ and ACME were 44.48 and 41.14 (min), it showed the biodiesel was good for fuel application, since ASTM of $47 \mathrm{~min}$ was the standard [25]. High cetane range guarantees great running of the engine. Cetane range indicates the degree of its ignition feature for compression ignition engines [36].

\subsubsection{Smoke, flash, fire and pour points}

The smoke, flash and fire points are temperatures that oil is heated and the mixture of vapor and air on top of the oil can go up in flames. These parameters provide information on the storage capability of the oil and usage safety. The smoke point values obtained from the $\mathrm{WCO}$ and $\mathrm{ACO}$ were $194^{\circ} \mathrm{C}$ and $139^{\circ} \mathrm{C}$ respectively. The smoke point of ACO decreased; but it had been over $130^{\circ} \mathrm{C}$. This inexplicit the oil won't be sensible for frying, but safe as fuel as a result of itsnot nonignition at cold temperature. The ACME (biodiesel) had slightly higher smoke point $\left(131^{\circ} \mathrm{C}\right)$, flash point $\left(146^{\circ} \mathrm{C}\right)$, fire point $\left(169^{\circ} \mathrm{C}\right)$ and pour point $\left(-17^{\circ} \mathrm{C}\right)$, whereas the $\mathrm{ACO}$ had smoke point $\left(139^{\circ} \mathrm{C}\right)$, flash point $\left(140^{\circ} \mathrm{C}\right)$, fire point $\left(145^{\circ} \mathrm{C}\right)$, and pour point $\left(-4^{\circ} \mathrm{C}\right)$, respectively. In line with Omojola, e al., [31], they reported the pour points (congealing temperature) of some WCOs like sunflower, oleomargarine, sunfoil and palmoil as $-8.65,0.3,-.9 .8$ and $10.25\left({ }^{\circ} \mathrm{C}\right)$ against the determined pour point of $-3^{\circ} \mathrm{C}$ reported for WCO in the current study. The value conforms to the specification prompted by ASTM, [5, 6].

\subsubsection{The higher heating values}

The value for biodiesel in European set minimum is $35 \mathrm{MJ} / \mathrm{kg}$ [37]. We obtained biodiesel combustion value of $42.01 \mathrm{MJ} / \mathrm{kg}$ that was on the far side of the specification suggested. Due to the high heat of combustion value, the biodiesel will function as substitute to fuel. The caloric value of biofuels could be a vital parameter for the comparison of fuel properties with fossil's diesel.

\subsection{Fatty acid profile of biodiesel}

Table 2 provides the fatty acids profiles of the $\mathrm{ACO}$ and $\mathrm{WCO}$ in relative to their retention time and proportional composition.

Table 2: Comparison of fatty acid profiles of waste and treated cooking oils

\begin{tabular}{llcll}
\hline & & Waste cooking oil (WCO) & \\
\hline Retention Time & Composition & Saturation & $\begin{array}{l}\text { Composition } \\
(\%)\end{array}$ & $\begin{array}{l}\text { Comparable } \\
\text { Difference }\end{array}$ \\
& & & 4.86 & - \\
\hline 21.37 & Octanoic acid & $(\mathrm{C} 10: 2)$ & 3.74 & - \\
23.01 & Benzoic acid & $(\mathrm{C} 11: 2)$ & 1.01 & - \\
32.85 & Hexadecanoic acid & $(\mathrm{C} 18: 2)$ & 6.42 & - \\
33.41 & 9-Octadecenoic acid & $(\mathrm{C} 19: 2)$ & 0.03 & - \\
36.92 & Octadecanoic acid & $(\mathrm{C} 20: 2)$ & 1.02 & - \\
39.52 & 9, 12, 15 Octadecatrienoic acid & $(\mathrm{C} 19: 2)$ & 29.85 & - \\
39.98 & Octadecanoic acid & $(\mathrm{C} 20: 2)$ & 10.02 & - \\
40.69 & Heptadecanoic acid & $(\mathrm{C} 19: 2)$ & 38.51 & - \\
41.08 & Pentadecanoic acid & $(\mathrm{C} 17: 2)$ & 6.42 & - \\
42.84 & 9-Octadecenoic acid & $(\mathrm{C} 21: 4)$ & 8.35 & 71.81 \\
& & Alkaline treated cooking oil (ACO) & 0.01 \\
14.50 & Octanoic acid & $(\mathrm{C} 10: 2)$ & 3.77 & 74.01 \\
15.87 & Benzoic acid & $(\mathrm{C} 18: 2)$ & 75.02 & 14.64 \\
22.0 & Hexadecanoic acid & $(\mathrm{C} 21: 4)$ & 0.47 & \\
42.84 & 9-Octadecenoic acid & & & \\
\hline
\end{tabular}




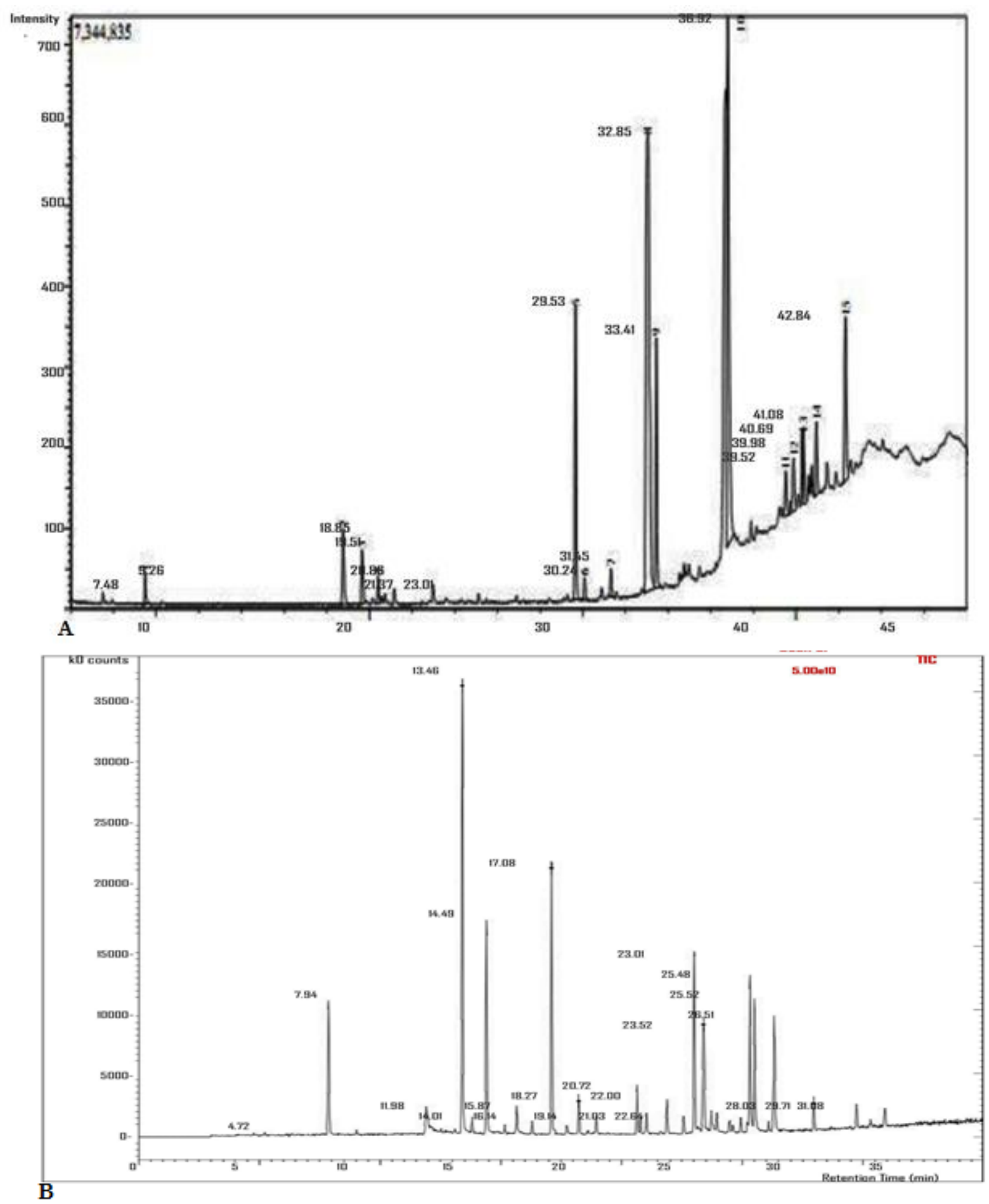

Figure 1: The GCMS chromatograms for both WCO (A) and ACO (B) based biodiesels

The fatty acids profile profile in ACO has octanoic acid (8.35\%), benzoic acid (3.77\%), and palmitic acid $(75.02 \%)$ was the foremost abundant. The 9-octadecenoic acid; octadecanoic acid; 9, 12, 15- octadecatrienoic acid and saturated fatty acid were found in WCO, but were not seen in the ACO as shown below in Figure 1

\subsection{The FTIR analysis of biodiesel}

In Table 3, Fourier Transform Infra-red (FTIR) foremost IR peak regions that indicated chemical changes were found at $1600-3600 \mathrm{~cm}-1$. The Fourier Transform Infra-red (FTIR) spectroscopic analysis results for biodiesel showed the foremost IR peak regions that indicated chemical changes. 
Table 3: Fourier Transform Infrared Spectroscopy analysis of biodiesels

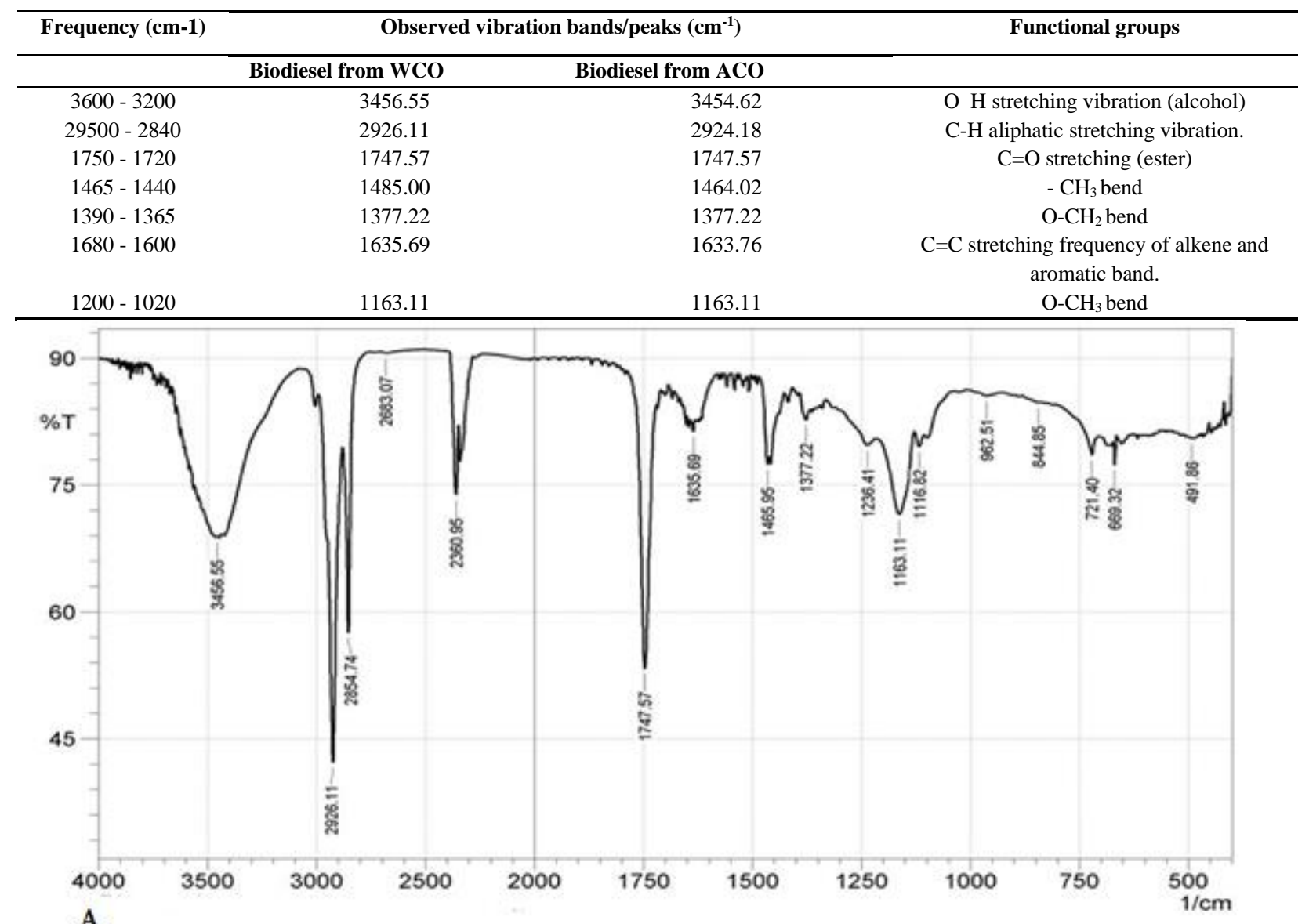

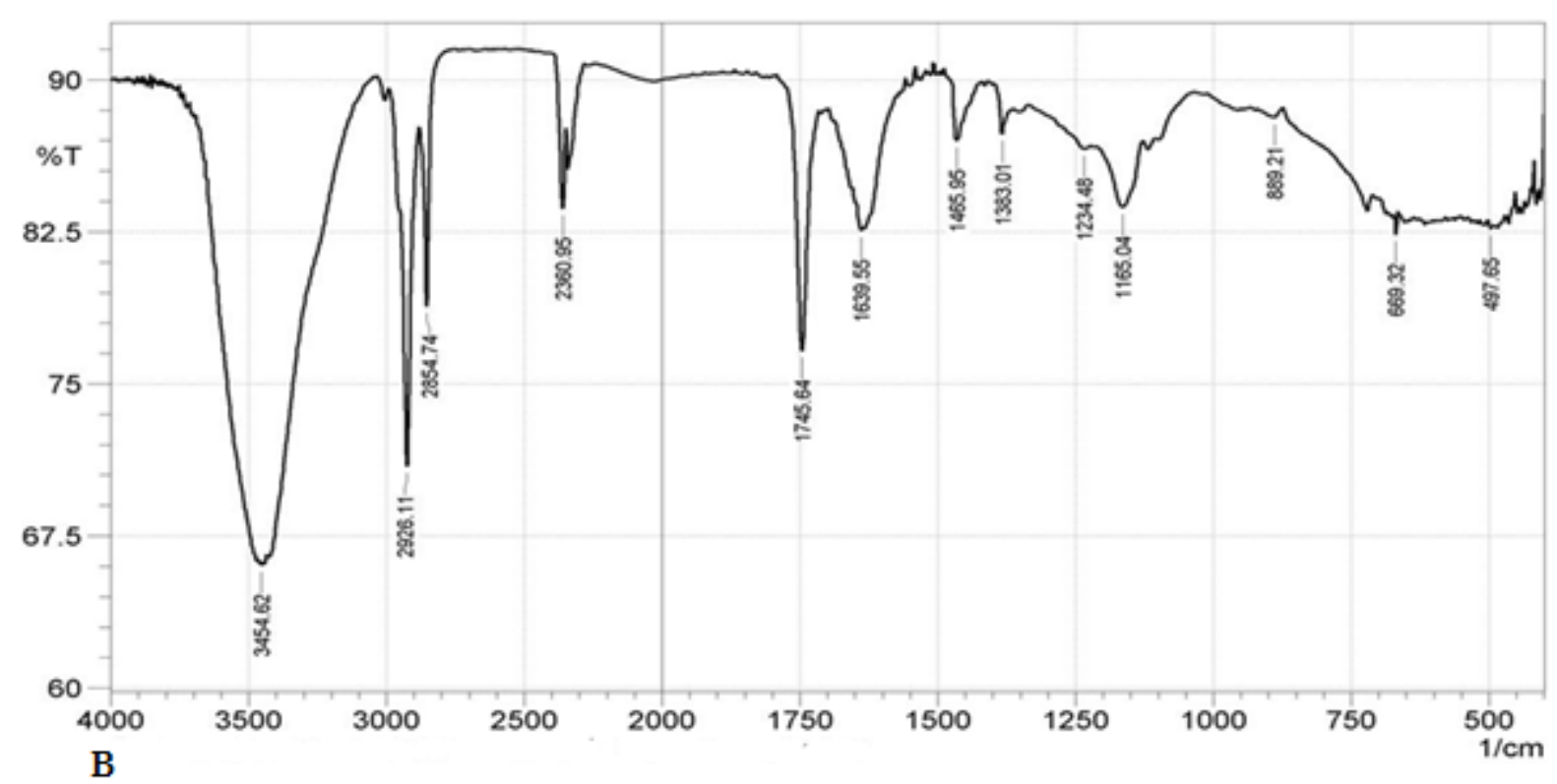

Figure 2: The FTIR spectral for both $W C O(A)$ and $A C O(B)$ based biodiesels

In Figure 2, the spectral bands $1377.22 \mathrm{~cm}^{-1}$ showed the presence of glycerol cluster $\mathrm{O}-\mathrm{CH}_{2}$ (mono, di and triglycerides) in both raw and refined oils. The IR spectral $1747.57 \mathrm{~cm}^{-1}$ in both samples corresponds to the presence of compound cluster among the WCO and ACO. IR band $1464.02-1485.00 \mathrm{~cm}^{-1}$ was as a result of its uneven bending and likewise matches with $-\mathrm{CH}_{3}$. 


\section{Conclusions}

Alkaline treatment of WCO has been demonstrated to optimize the transesterification process of industrially important alkyl ester (biodiesel) from waste cooking oil. The biodiesel from the refined oil has shown the foremost effective approach for the reduction of interfering contaminants within the WCO. The ACO that was produced have enhanced properties for emulsification for biodiesel production. The fuel properties of the neat biodiesel showed quality similar to the American Society for Test and Material - ASTM Quality Evaluations.

\section{Competing Interests}

The authors declared that no conflict of interest exist in this publication.

\section{How to Cite this Article:}

Aliru Olajide Mustapha et al., "Characterization of Biodiesel from Alkaline Refinement of Waste Cooking Oil", Int. Ann. Sci., vol. 10, no. 1, pp. 16-24, Sep. 2020.

\section{References}

[1] M Tabatabaei, M Aghbashlo, M Dehhaghi, H.K.S Panahi, "Mollahosseini A., Hosseini M., Soufiyan M.M. Reactor technologies for biodiesel production and processing: A review:", Prog in Energy and Comb Sci,74. 2019 https://doi.org/10.1016/j.pecs.2019.06.001

[2] A K Sharma, P. KSharma, V Chintala, N Khatri, Alok Patel, "Environment-Friendly Biodiesel/Diesel Blends for Improving the Exhaust Emission and Engine Performance to Reduce the Pollutants Emitted from Transportation Fleets," Int. J. Environ. Res. Public Health, 17, 3896, 2020.

[3] E.W Eckey, "Esterification and interesterification. $J$ of Ame Oil Chemists Soc. 33, 575-579, 2010. https://doi.org/10.1007/BF02638493

[4] G Chiriboga, A De La Rosa, C Molina, S Velarde, C.G "Carvajal Energy Return on Investment (EROI) and Life Cycle Analysis (LCA) of biofuels in Ecuador," .Heliyon. 6, 6: $\quad$ e 04213. doi:10.1016/j.heliyon.2020.e04213

[5] B. Thangaraj, P.R Solomon, B Muniyandi, S Ranganathan, L Lin, "Catalysis in biodiesel production - a review," Clean Energy, 3, 1, 2-23, 2019 https://doi.org/10.1093/ce/zky020

[6] F Ishola, D Adelekan, A Mamudu, T Abodunrin, A Aworinde, O Olatunji, S Akinlabi, "Biodiesel production from palm olein: A sustainable bioresource for Nigeria," Heliyon 6, e03725, 2020

[7] S SanaSadaf, J Iqbal, I Ullah, H.N Bhatt, S Noure, H Jan, N M.Iqbal, "Biodiesel production from waste cooking oil: An efficient technique to convert waste into biodiesel". Sustainable Cities and Society. 41, 220-226, 2018 https://doi.org/10.1016/j.scs.2018.05.037
[8] Y Mnam, Z Nwm, S NL, "Sustainability of Palm Biodiesel in Transportation: a Review on Biofuel Standard, Policy and International Collaboration Between Malaysia and Colombia. Bioenergy Res. 118, 2020. doi:10.1007/s12155-020-10165-0

[9] S Adeyinka. Y Adeyinka, S Yusuff, O David, A Olalekan, D Adeniyi , M Olutoye, M Olutoye, U. G. Akpan, "Development and Characterization of a Composite Anthill-chicken Eggshell Catalyst for Biodiesel Production from Waste Frying Oil," Int J of Technol, 9, 1, 110., 2018. https://doi.org/10.14716/ijtech.v9i1.1166

[10] F Jafarihaghighi, M Ardjmand, M Salar Hassani, M Mirzajanzadeh, H Bahrami, “ Effect of Fatty Acid Profiles and Molecular Structures of Nine New Source of Biodiesel on Combustion and Emission,"ACS Omega, 5, 26, 16053-16063, 2020. doi:10.1021/acsomega.0c01526

[11] M.J Haas, A.J McAloon, W.C Yee, T.A Foglia,. "A process model to estimate biodiesel production costs", Biores Technol. 97, 671-678, 2006 https://doi.org/10.1016/j.biortech.2005.03.039

[12] S Kumar, S Jain, H Kumar, "Experimental Study on Biodiesel Production Parameter Optimization of Jatropha-Algae Oil Mixtures and Performance and Emission Analysis of a Diesel Engine Coupled with a Generator Fueled with Diesel/Biodiesel Blends," ACS Omega. $\quad 5, \quad 28, \quad 17033-17041, \quad 2020$ doi:10.1021/acsomega.9b04372

[13] M.G Kulkarni and A.K. Dalai, "Waste cooking oil- An Economical Source for Biodiesel: A Review", Ind \& Eng Chem Res. 45, 9, 2901-2913, 2006. https://doi.org/10.1021/ie 0510526

[14] L Amin, H Hashim, Z Mahadi, M Ibrahim, K Ismail, "Determinants of stakeholders' attitudes towards biodiesel," Biotechnol Biofuels, 10, 219, 2017. doi:10.1186/s13068-017-0908-8

[15] O Idoko, M.D Bwai, S.A Emmanuel, S.A Thomas, "Effect of bleaching and degumming on the physicochemical Properties and antioxidant activity of palm oil", Res $J$ in Eng and Appl Sci. 2, 5,343-345, 2013.

[16] P.M Mitrović, O. S Stamenković, I Banković, "White Mustard (Sinapis alba L.) Oil in Biodiesel Production: A Review. Front Plant Sci. 11, 299, 2020 doi:10.3389/fpls.2020.00299

[17] R.O. Olaoluwa, S. A. Abolanle, A. O. O. John, M. O Efere, S. O. Olatunji, M. S. Adedayo, A. A. Muib, M. A. Oyedare, "Refining, Toxicology Study and Biodiesel Potentials of Used Vegetable Oils", Ame J of Food Sci and Technol. 5, 3, 78-88, 2017

[18] M Gojun, M Bačić, A Ljubić, A Šalić, B Zelić, "Transesterification in Microreactors-Overstepping Obstacles and Shifting Towards Biodiesel Production on a Microscale," Micromachines (Basel). 11, 5, 457, 2020. doi:10.3390/mi11050457

[19] E.S Rahadianti, Yerizam and Martha, "Biodiesel production from waste cooking oil. Indones. $J$ of Fundam Appl Chem. 3, 3, 77-82, 2018 https://doi.org/10.24845/ijfac.v3.i3.77

[20] H E Touliabah, M I Abdel-Hamid, A.W Almutairi, "Long-term monitoring of the biomass and production of lipids by Nitzschia palea for biodiesel production," Saudi J Biol Sci. 27, 8, 2038-2046, 2020 doi:10.1016/j.sjbs.2020.04.014 
Aliru Olajide Mustapha et al., Int. Ann. Sci.; Vol. 10, Issue 1, pp: 16-24, 2021

[21] I.E. Akubugwo, V. Chinyere, A.E. Ugbogu. "Comparative Studies on Oil from Some Common Plant Seeds in Nigeria". Pak J of Nutr, 7, 4, 570-573, 2008. https://doi.org/10.3923/pjn.2008.570.573

[22] L M Baena, J A Calderón, "Effects of palm biodiesel and blends of biodiesel with organic acids on metals," Heliyon;6, 5, :e03735, 2020 doi:10.1016/j.heliyon.2020.e03735

[23] AOAC, Official methods of analysis, Association of official analytical chemist 19th edition, Washington D.C., USA. 2012.

[24] S I Akinfalabi, U Rashid, I Arbi Nehdi, T S Yaw Choong, H M Sbihi, M M Gewi, "Optimization and blends study of heterogeneous acid catalyst-assisted esterification of palm oil industry by-product for biodiesel production," R Soc Open Sci. 7, 1, 191592, 2020. doi:10.1098/rsos.191592

[25] American Society for Testing Materials (ASTM). ASTM Standards Methods: ASTM pub; Philadelphia. 2003

[26] AOCS. Official Method Cd 3d-63: Acid value in fats and oils. American Oil Chemists' Society, Champaign, Illinois, USA. 2006.

[27] AOCS, Official Method Cd 8-53: Peroxides in fats and oils. American Oil Chemists' Society, Champaign, Illinois, USA. 2006.

[28] AOCS, Official Method Ca 5a-40: Free fatty acids. American Oil Chemists' Society, Champaign, Illinois, USA. 2006.

[29] T Leevijit, $\mathrm{G}$ Prateepchaikul, $\mathrm{K}$ Maliwan, $\mathrm{P}$ Mompiboon, S Okaew, S Eiadtrong, "Production, properties, and utilization of degummed/esterified mixed crude palm oil-diesel blends in an automotive engine without preheating", Fuel, 182, 509-516, 2016. https://doi.org/10.1016/j.fuel.2016.06.007

[30] A Mohammed, R Bhargavi, "Biodiesel production from waste cooking oil", J of Chem. and Pharm Res. 7, 12, 670-681, 2015.

[31] A Omojola, I.O. Emmanuel, L. I. Freddie, "Comparative study of properties and fatty acid composition of some neat vegetable oils and waste cooking oils" Int J of Low-Carbon Technol, 14, 417425, 2019. https://doi.org/10.1093/ijlct/ctz038

[32] A. Adewuyi, R.A Oderinde, I. A. Ajayi, "The metal composition, proximate properties and the effect of refining on the physico-chemical characterization of Baphia nitida and Gliricidia sepium seed and seed oil" $J$ of Food Technol, 7,2, 43-49, 2009

[33] T.W. Ryan, L.G. Dodge, T.J. Callahan, "The effects of vegetable oil properties on injection and combustion in two different diesel engines" J Ame Oil Chem Soc, 61, 1610-1619, 1984. https://doi.org/10.1007/BF02541645

[34] D. P. Prafulla., G. Veera, K. R. Harvind, M. Tapaswy, D. Shuguang, "Biodiesel Production for Waste Cooking Oil Using Sulfuric Acid and Microwave Irradiation Process" J of Environ Prot. 3, 107-113, 2012. https://doi.org/10.4236/jep.2012.31013

[35] C. Maurizio, C Sonia, C. Silvia, “A Pilot-Scale Study of Waste Vegetable Oil Transesterification with Alkaline and Acidic Catalysts" Energy Procedia. 45, 198 - 206, 2014. https://doi.org/10.1016/j.egypro.2014.01.022

[36] CODEX Alimentarius Commisions, Recommended International Standards for Edible Arachis Oil'. Food and Agricultural Organization of the United Nation.
World Health Organizaton, Geneva, Switzerland, 1, 619, 1992.

[37] EN14214, Automotive fuels-fatty acid methyl esters (FAME) for diesel engines-requirements and test methods, Berling, Germany: Beuth-Verlag. 2003.

[38] A Duhan, S Duhan, B Kumari, "Effect of Chemical Refining on Citrullus Colocynthis and Pongamia Pinnata Seed Oil" Afri J of Food, Agric, Nutr and Devept $12,3,2012$

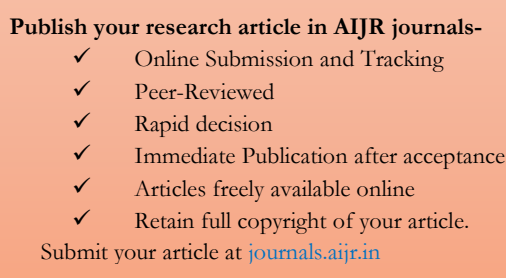

Publish your books with AIJR publisher-

$\checkmark \quad$ Publish with ISBN and DOI.

$\checkmark \quad$ Publish Thesis/Dissertation as Monograph.

$\checkmark \quad$ Publish Book Monograph.

$\checkmark \quad$ Publish Edited Volume/ Book.

$\checkmark \quad$ Publish Conference Proceedings

$\checkmark \quad$ Retain full copyright of your books.

Submit your manuscript at books,aijr.org 